\title{
Analisis Zonasi Kerentanan Banjir di Kabupaten Aceh Singkil
}

\author{
(Zoning Analysis of Flood Vulnerability in District Aceh Singkil)
}

\author{
Oktri Sri Wahyuni ${ }^{1}$, Muhammad Rusdi ${ }^{1}$, Hairul Basri ${ }^{1 *}$ \\ ${ }^{1}$ Program Studi Ilmu Tanah, Fakultas Pertanian, Universitas Syiah Kuala \\ *Corresponding author:hairulbasri@unsyiah.ac.id
}

\begin{abstract}
Abstrak. Banjir adalah bencana hidrometeorologi yang sering terjadi dan sulit diduga karena datang secara tiba-tiba dengan periodisitas yang tidak menentu. Daerah rentan banjir adalah daerah yang mudah atau mempunyai kecenderungan untuk terlanda banjir. Kabupaten Aceh Singkil termasuk daerah yang rentan bencana alam dan salah satu permasalahan yang sering terjadi setiap tahunnya pada musim penghujan adalah masalah banjir. Tujuan dari penelitian ini adalah untuk membuat zonasi daerah kerentanan banjir di Kabupaten Aceh Singkil. Metode penelitian ini menggunakan Weighted Sum Overlay yang didalamnya melibatkan skoring dan pembobotan. Tingkat kerentanan banjir ditentukan berdasarkan parameter yang berpengaruh terhadap banjir yaitu curah hujan, kemiringan lereng, ketinggian lahan, penggunaan lahan, dan jenis tanah. Aplikasi Sistem Informasi Geografis digunakan sebagai permodelan spasial dalam memetakan kerentanan banjir dan hasilnya diinterpretasikan dalam bentuk peta. Hasil penelitian menunjukan bahwa zona agak rentan 60,31 ha $(0,04 \%)$, rentan $17.132,30$ ha $(9,22 \%)$, dan sangat rentan 168.590 ha $(90,74 \%)$.
\end{abstract}

Kata Kunci: Kerentanan Banjir, Weighted Sum Overlay

Abstract. Floods are hydrometeorological disasters that often occur and are difficult to predict because they come suddenly with uncertain periodicity. Flood prone areas are areas that are prone to or have a tendency to be flooded. Aceh Singkil Regency is one of the areas prone to natural disasters and one of the problems that often occurs every year in the rainy season is the problem of flooding. The purpose of this research is to zoning flood susceptibility areas in Aceh Singkil District. This research method uses a Weighted Sum Overlay which involves scoring and weighting. The level of flood vulnerability is determined based on the parameters that affect flooding, namely rainfall, slope, land height, land use, and soil type. Geographical Information System application is used as spatial modeling in mapping flood vulnerability and the results are interpreted in the form of a map. The results showed that the zone was slightly vulnerable 60.31 ha $(0.04 \%)$, vulnerable $17,132.30$ ha $(9.22 \%)$, and very vulnerable 168,590 ha $(90.74 \%)$.

Keywords: Flood Vulnerability, Weighted Sum Overlay

\section{PENDAHULUAN}

Bencana dapat didefinisikan sebagai peristiwa yang mengancam dan mengganggu kehidupan atau penghidupan masyarakat yang disebabkan baik oleh faktor alam dan/atau faktor non alam maupun faktor manusia (Undang-undang No. 24 Tahun 2007 tentang Penanggulangan Bencana). Banjir merupakan kejadian alam yang sulit diduga karena datang secara tiba-tiba dengan periodisitas yang tidak menentu, kecuali daerah-daerah yang sudah menjadi langganan terjadinya banjir tahunan. Sedikitnya ada lima faktor penting penyebab banjir di Indonesia yaitu faktor hujan, faktor retensi daerah aliran sungai (DAS) berkurang, 
faktor kesalahan perencanaan pembangunan alur sungai, faktor pendangkalan sungai dan faktor kesalahan tata wilayah dan pembangunan sarana dan prasarana (Maryono, 2005).

Sistem informasi geografis (SIG) merupakan salah satu aplikasi yang dapat mengidentifikasi dan pemetaan kawasan yang berpotensi banjir. Untuk kajian banjir, peta tematik hasil interpretasi citra dapat digabung dengan peta-peta lainnya yang disusun dalam data SIG melalui proses digitisasi. Peta-peta tersebut adalah peta kemiringan lereng, peta jenis tanah, peta pengunaan lahan dan peta curah hujan (Utomo, 2004). Kelas-kelas rawan banjir dihasilkan melalui metode overlay pembobotan dengan menggunakan metode weighted sum overlay. Metode weighted sum overlay merupakan metode yang dapat menghitung skor dan bobot dari beberapa input secara bersamaan. Metode ini juga memiliki kelebihan dalam hal kecepatan pemrosesan, kemudahan dalam penyajian, lebih efektif dan efisien serta akurat (Syukran, 2016).

Kabupaten Aceh Singkil mempunyai histori kejadian banjir yang cukup sering terjadi setiap tahunnya. Curah hujan yang tinggi dan topografi yang rendah menambah resiko mudahnya terjadi banjir. Risiko dan dampak terhadap timbulnya bencana banjir yang sering terjadi di Kabupaten Aceh Singkil dapat diminimalisasi dengan melakukan persiapan dan pencegahan terhadap bencana banjir. Salah satu yang dapat dilakukan adalah mengenal dan mengetahui wilayah yang berpotensi banjir.

\section{METODE PENELITIAN}

Penelitian ini dilaksanakan di Kabupaten Aceh Singkil dengan luas wilayah \pm 185 $\mathrm{km}^{2}$. Alat yang digunakan dalam penelitian ini ialah perangkat keras (hardware) yang terdiri dari laptop, kamera, global positioning system (GPS), dan printer, sedangkan perangkat lunak (software) meliputi ArcGIS, microsoft excel, dan microsoft word. Sedangkan bahan yang digunakan dalam penelitian ini meliputi data dari lapangan seperti peta administrasi dan tematik yang berkaitan dengan penelitian.

Metode yang digunakan pada penelitian ini adalah Weighted Sum Overlay. Teknik ini menggabungkan skoring setiap kelas parameter dan juga pembobotan masing-masing parameter secara bersamaan. Kemudian setiap parameter di tumpangtindihkan dan menghasilkan peta sebaran kerentanan banjir di Kabupaten Aceh Singkil. 
Data yang dikumpulkan berupa skor dan bobot setiap parameter dan juga peta administrasi serta tematik yaitu curah hujan, lereng, ketinggian lahan, penggunaan lahan, dan jenis tanah. Kemudian untuk mengetahui sebaran banjirnya menggunakan tools Weighted Sum Overlay yang disediakan di ArcGIS. Diagram alir penelitian dapat dilihat pada Gambar 1.

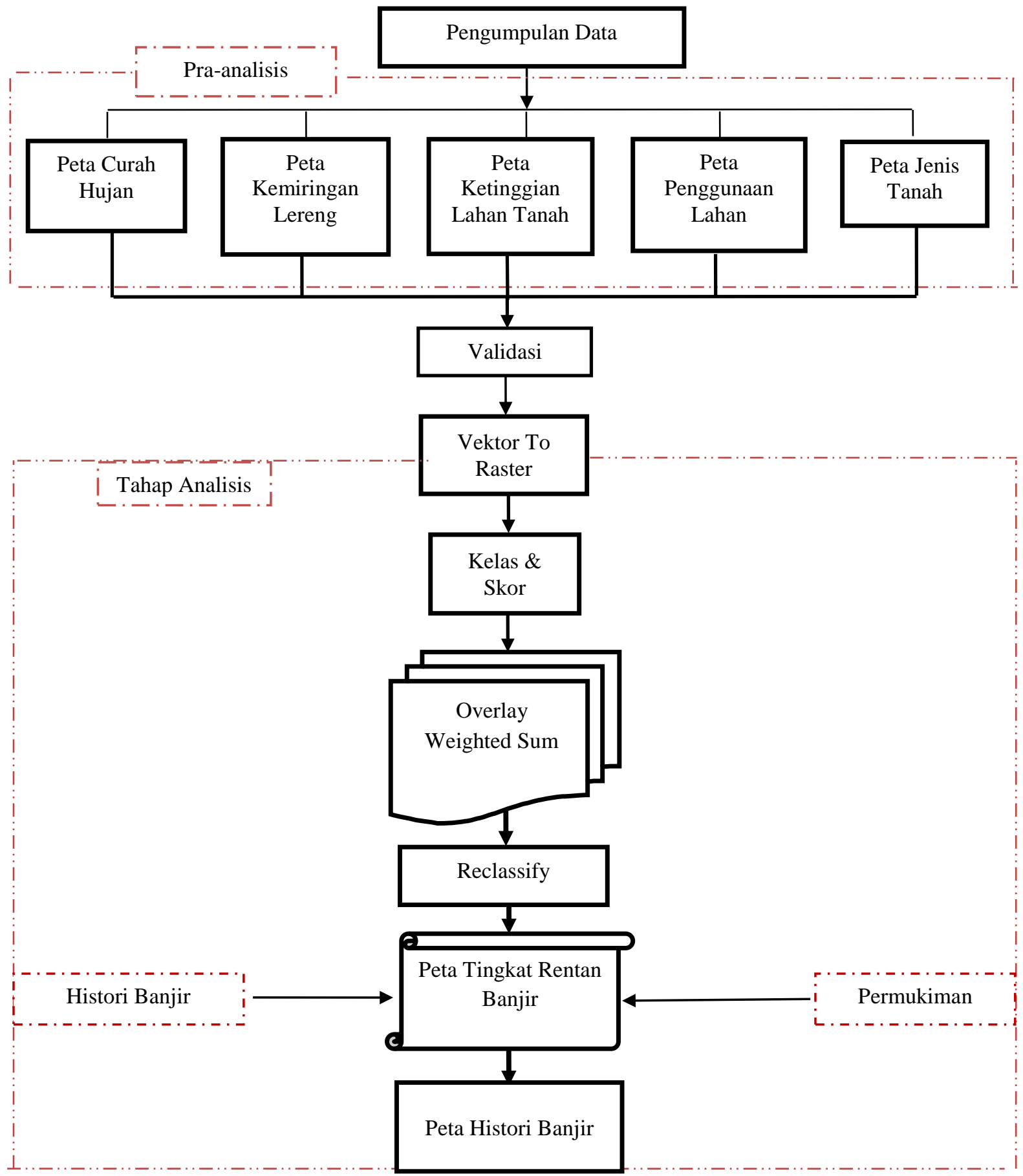

Gambar 1. Diagram Alir Penelitian 
Kelas kerentanan banjir didapatkan dari Puslitanak Bogor 2004. Penentuan zonasi kerentanan banjir berdasarkan jumlah skor dari seluruh indikator yang dikalikan dengan bobot serta memberikan kriteria tingkat kerentanan banjir. Indeks kerentanan banjir tertinggi yang diperoleh adalah 4,8, dan indeks terendah yang diperoleh adalah 0,7. Secara matematis, perhitungan interval dapat dilhat di bawah ini.

Kelas Interval (i) $=\frac{\text { Selisih Skor Tertinggi-Selisih Skor Terendah }}{\text { jumlah kelas }}$

Kelas Interval $(i)=\frac{4,8-0,7}{4}$

$$
=1,025
$$

\section{HASIL DAN PEMBAHASAN}

\section{Curah Hujan}

Informasi curah hujan dilokasi penelitian diperoleh dari perhitungan data curah hujan dan analisis peta dengan polygon thiesen. Seluruh wilayah di Kabupaten Aceh Singkil memiliki curah hujan yang tergolong sangat tinggi dengan curah hujan $>3000 \mathrm{~mm} / \mathrm{tahun}$. Sebaran curah hujan pada lokasi penelitian disajikan pada Tabel 1 dan peta curah hujan dapat dilihat pada Gambar 2.

Tabel 1. Sebaran Luas Curah Hujan Kabupaten Aceh Singkil

\begin{tabular}{|c|c|c|c|c|c|}
\hline No & Pos Hujan & $\begin{array}{c}\text { Curah } \\
\text { Hujan(mm/tahun) }\end{array}$ & Klasifikasi & Hektar & Persentase \\
\hline 1 & Rundeng & 3436 & Sangat Tinggi & $9.625,59$ & 5,18 \\
\hline 2 & Keb.Lae Butar & 3837 & Sangat Tinggi & $154.609,99$ & 83,21 \\
\hline 3 & Simpang Kiri & 4080 & Sangat Tinggi & $21.567,04$ & 11,61 \\
\hline \multicolumn{4}{|c|}{ Total } & $185.802,62$ & 100 \\
\hline
\end{tabular}




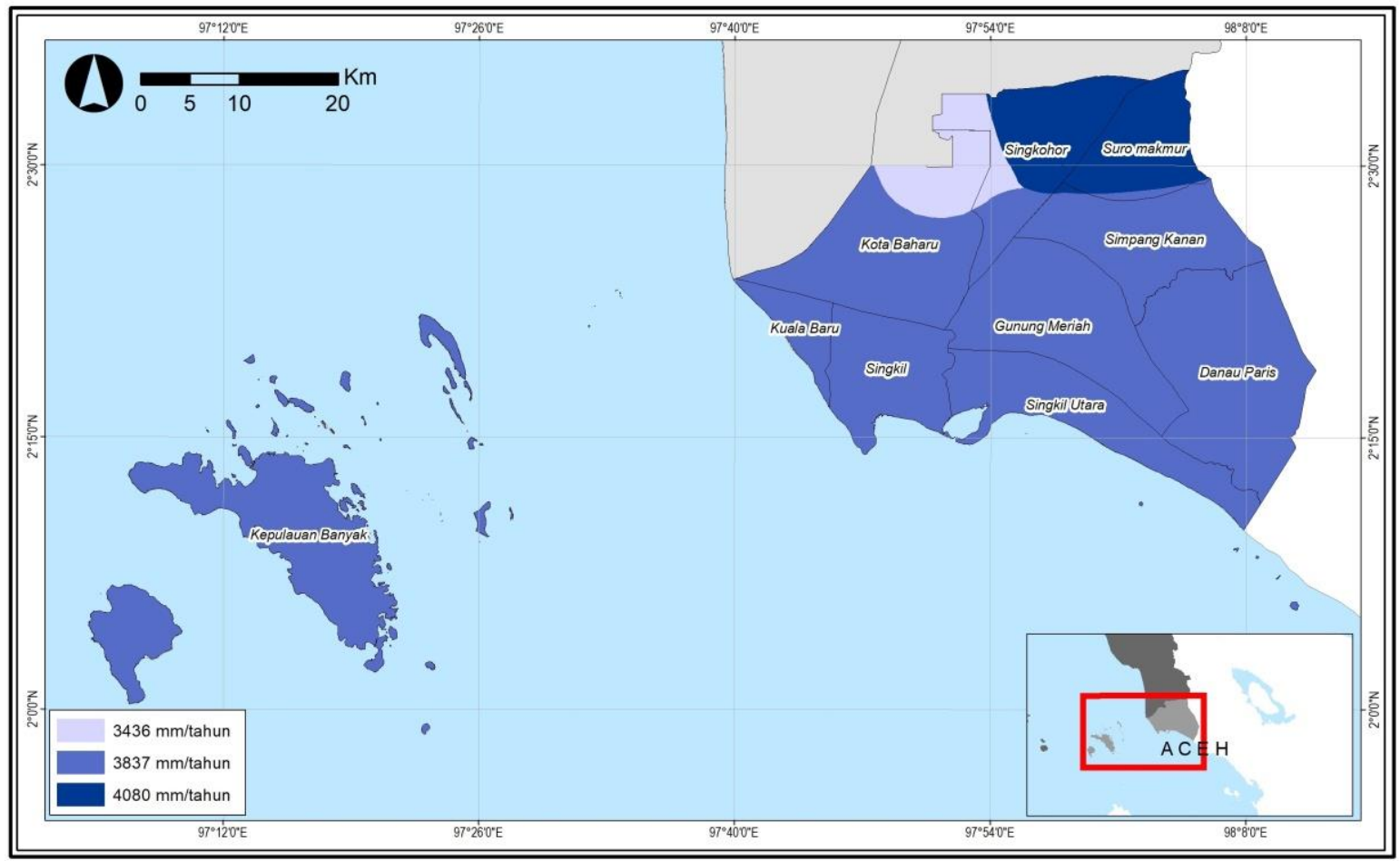

Gambar 2. Peta Curah Hujan Kabupaten Aceh Singkil

\section{Kemiringan Lereng}

Kemiringan lereng atau kelas lereng di Kabupaten Aceh Singkil dibagi lima kelas kemiringan, yaitu kelas datar (0-8\%), landai (8-15\%), agak curam (15-30\%), curam (30-45\%), dan sangat curam $(>45 \%)$. Sebaran luas kemiringan lereng dapat dilihat pada tabel 2 dan secara virtual peta kemiringan lereng disajikan pada Gambar 3.

Tabel 2. Sebaran Luas Kemiringan Lereng Kabupaten Aceh Singkil

\begin{tabular}{cccrr}
\hline No & Kemiringan(\%) & Klasifikasi & Hektar & Persentase \\
\hline 1 & $0-8 \%$ & Datar & $171.092,99$ & 92,08 \\
2 & $8-15 \%$ & Landai & $11.601,56$ & 6,24 \\
3 & $15-30 \%$ & Agak Curam & $2.857,27$ & 1,54 \\
4 & $30-45 \%$ & Curam & 192,68 & 0.10 \\
5 & $>45 \%$ & Sangat Curam & 58,12 & 0,03 \\
\hline & Total & & $185.802,62$ & 100 \\
\hline
\end{tabular}




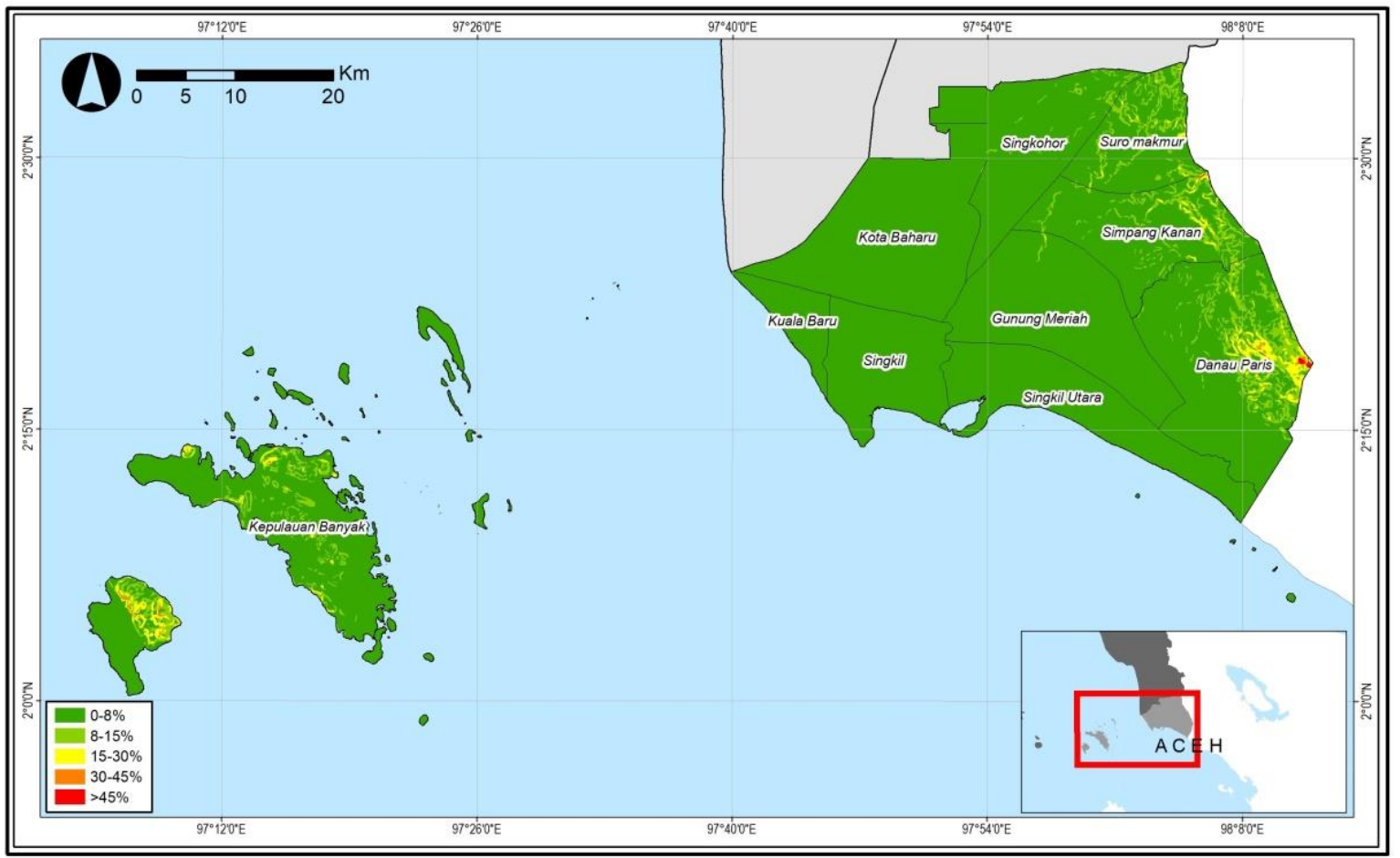

Gambar 3. Peta Kemiringan Lereng Kabupaten Aceh Singkil

\section{Ketinggian Lahan}

Hasil analisis menunjukkan bahwa ketinggian lahan di Kabupaten Aceh Singkil digolongkan kedalam 5 kelas ketinggian yaitu: datar (0m-50m), landai $(50 \mathrm{~m}-100 \mathrm{~m})$, agak curam $(100 \mathrm{~m}-150 \mathrm{~m})$, curam $(150 \mathrm{~m}-300 \mathrm{~m})$, dan sangat curam $(>300 \mathrm{~m})$. Sebaran luas ketinggian lahan disajikan pada tabel 3 dan peta ketinggian lahan Kabupaten Aceh Singkil dapat dilihat pada Gambar 4 .

Tabel 3. Sebaran Luas Ketinggian Lahan Kabupaten Aceh Singkil

\begin{tabular}{cccrr}
\hline No & Ketinggian $(\mathbf{m})$ & Klasifikasi & Hektar & Persentase \\
\hline 1 & $0 \mathrm{~m}-50 \mathrm{~m}$ & Datar & $120.285,08$ & 64,74 \\
2 & $50 \mathrm{~m}-100 \mathrm{~m}$ & Landai & $41.512,51$ & 22,34 \\
3 & $100 \mathrm{~m}-150 \mathrm{~m}$ & Agak Curam & $17.317,21$ & 9,32 \\
4 & $150 \mathrm{~m}-300 \mathrm{~m}$ & Curam & $5.674,30$ & 3,05 \\
5 & $>300 \mathrm{~m}$ & Sangat Curam & $1.013,53$ & 0,55 \\
\hline & Total & & $185.802,62$ & 100 \\
\hline
\end{tabular}




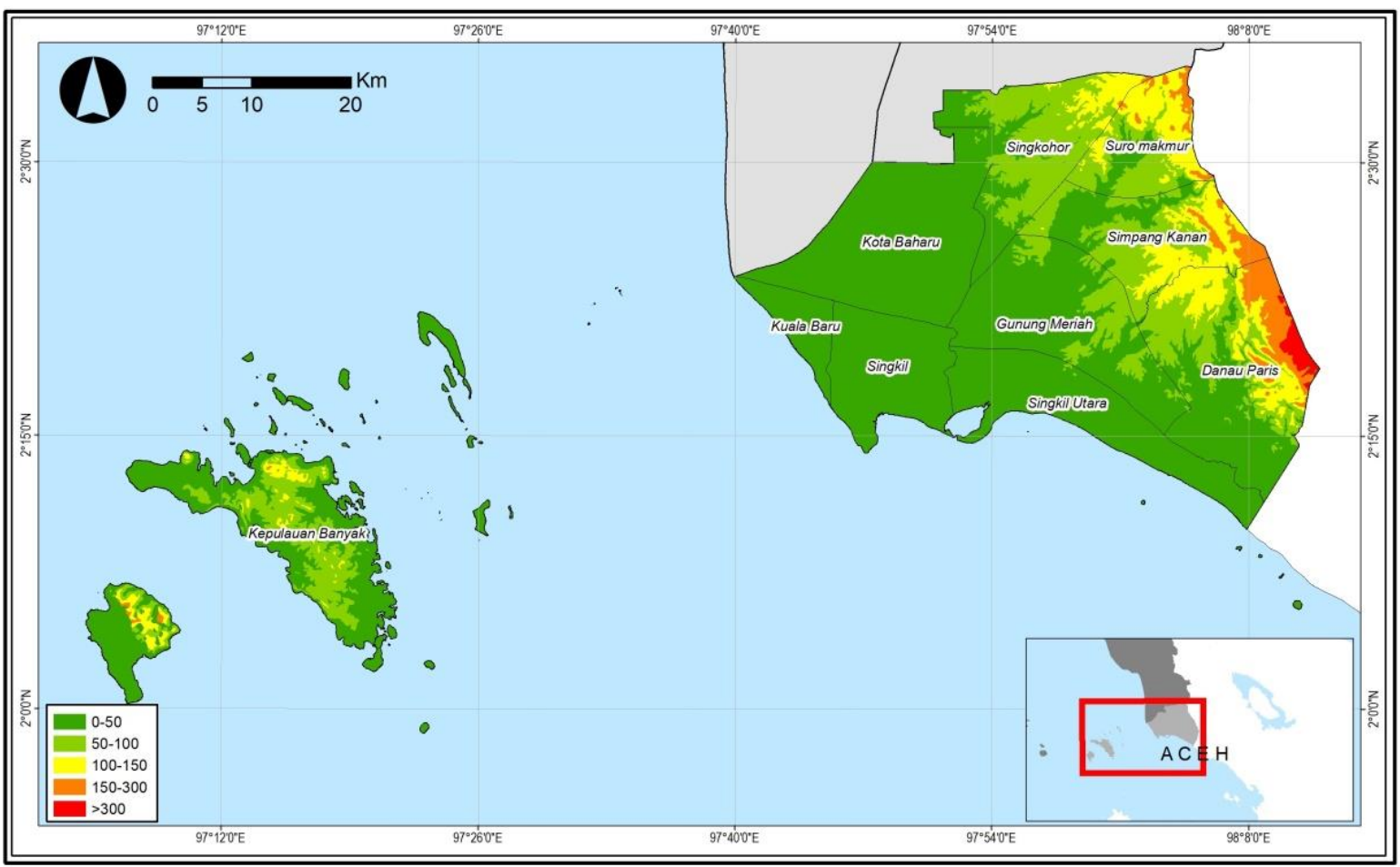

Gambar 4. Peta Ketinggian Lahan Kabupaten Aceh Singkil

\section{Penggunaan Lahan}

Informasi penggunaan lahan diperoleh dari analisis peta penggunaan lahan dan diketahui bahwa Kabupaten Aceh Singkil didominasi oleh penggunaan lahan berupa perkebunan. Sebaran luas penggunaan lahan disajikan dalam tabel 4 dan peta penggunaan lahan dapat dilihat pada Gambar 5.

Tabel 4. Sebaran Luas Penggunaan Lahan Kabupaten Aceh Singkil

\begin{tabular}{clrr}
\hline No & Penggunaan Lahan & Hektar & Persentase \\
\hline 1 & Sungai & $3.072,66$ & 1,65 \\
2 & Pemukiman & $2.446,89$ & 1,32 \\
3 & Rawa & $23.211,50$ & 12,49 \\
4 & Sawah & 208,32 & 0,11 \\
5 & Kebun Campuran & $24.216,43$ & 13,03 \\
6 & Semak & 220,43 & 0,12 \\
7 & Perkebunan & $95.447,16$ & 51,37 \\
8 & Hutan Lebat & $12.286,10$ & 6,61 \\
9 & Taman Wisata Alam Pulau Banyak Darat & $24.693,12$ & 13,29 \\
\hline \multicolumn{2}{r}{ Total } \\
\hline
\end{tabular}




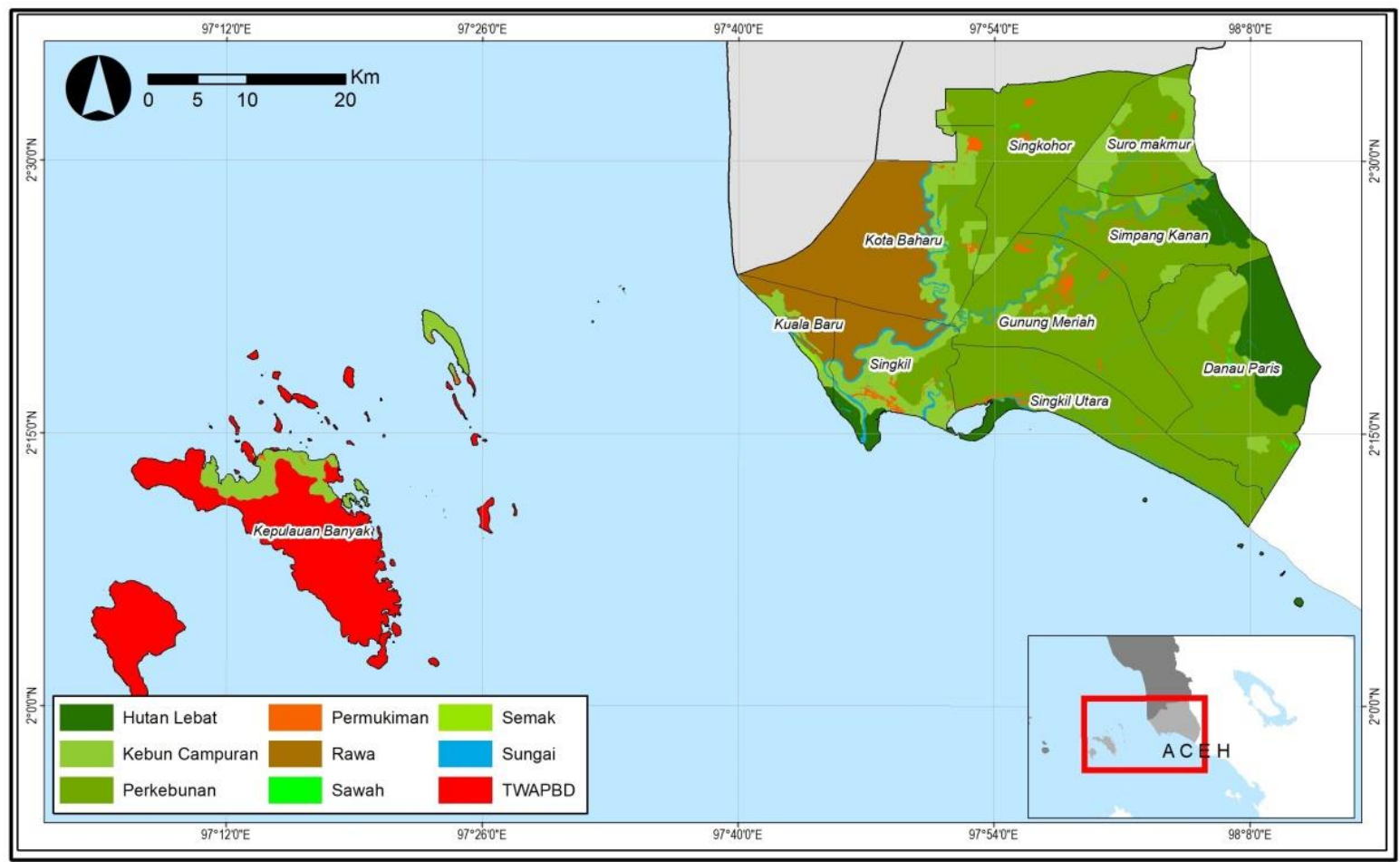

Gambar 5. Peta Penggunaan Lahan Kabupaten Aceh Singkil

\section{Jenis Tanah}

Informasi jenis tanah dilokasi penelitian diperoleh dari BAPPEDA Aceh dan berdasarkan peta diketahui bahwa jenis tanah di Kabupaten Aceh Singkil menurut USDA dibagi menjadi 4 ordo tanah yaitu Histosol, Inceptisol, Ultisol, Vertisol. Sebaran luas jenis tanah kabupaten Aceh Singkil ditunjukkan pada Tabel 5 dan peta jenis tanah kabupaten Aceh Singkil disajikan pada Gambar 6.

Tabel 5. Sebaran Luas Jenis Tanah Kabupaten Aceh Singkil

\begin{tabular}{ccrr}
\hline No & Jenis Tanah(USDA) & Hektar & Persentase \\
\hline 1 & Histosol & $30.488,03$ & 16,41 \\
2 & Inceptisol & $42.913,35$ & 23,10 \\
3 & Ultisol & $106.500,42$ & 57,32 \\
4 & Vertisol & $5.900,81$ & 3,18 \\
\hline & Total & $185.802,62$ & 100 \\
\hline
\end{tabular}




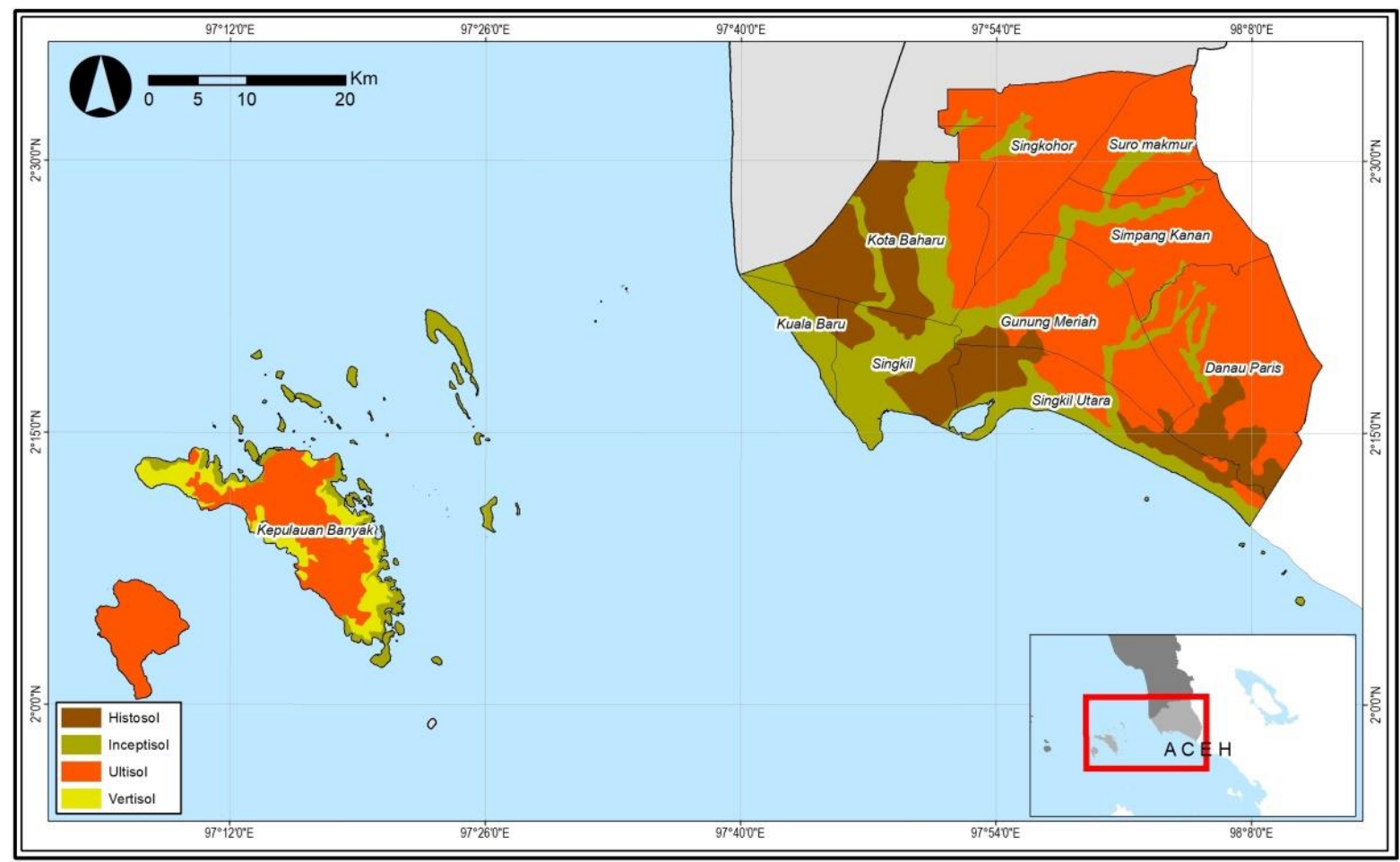

Gambar 6. Peta Jenis Tanah Kabupaten Aceh Singkil

\section{Zonasi Tingkat Kerentanan Banjir}

Peta kerentanan banjir dihasilkan dari metode Weighted Sum Overlay dengan menumpangtindihkan parameter curah hujan, kemiringan lereng, ketinggian lahan, penggunaan lahan, dan jenis tanah. Distribusi kerentanan banjir di Kabupaten Aceh Singkil dibagi kedalam 3 zona yaitu agak rentan, rentan dan sangat rentan. Zona kerentanan paling luas berada pada kelas sangat rentan dengan persentase 90,74\%. Sementara itu, zona yang paling sedikit memiliki luas $0,04 \%$ dari wilayah penelitian. Secara rinci distribusi daerah rentan banjir pada lokasi penelitian dapat dilihat pada Tabel 6 dan peta distribusi kerentanan banjir dapat dilihat pada Gambar 7.

Tabel 6. Distribusi Kerentanan Banjir

\begin{tabular}{cccrr}
\hline No & Nilai & Tingkat Kerentanan & Hektar & Persentase \\
\hline 1 & $1,7-2,7$ & Zona Agak Rentan & 80,31 & 0,04 \\
2 & $2,7-3,7$ & Zona Rentan & $17.132,30$ & 9,22 \\
3 & $3,7-4,8$ & Zona Sangat Rentan & 168.590 & 90,74 \\
\hline \multicolumn{3}{c}{ Total } & $185.802,62$ & 100 \\
\hline
\end{tabular}




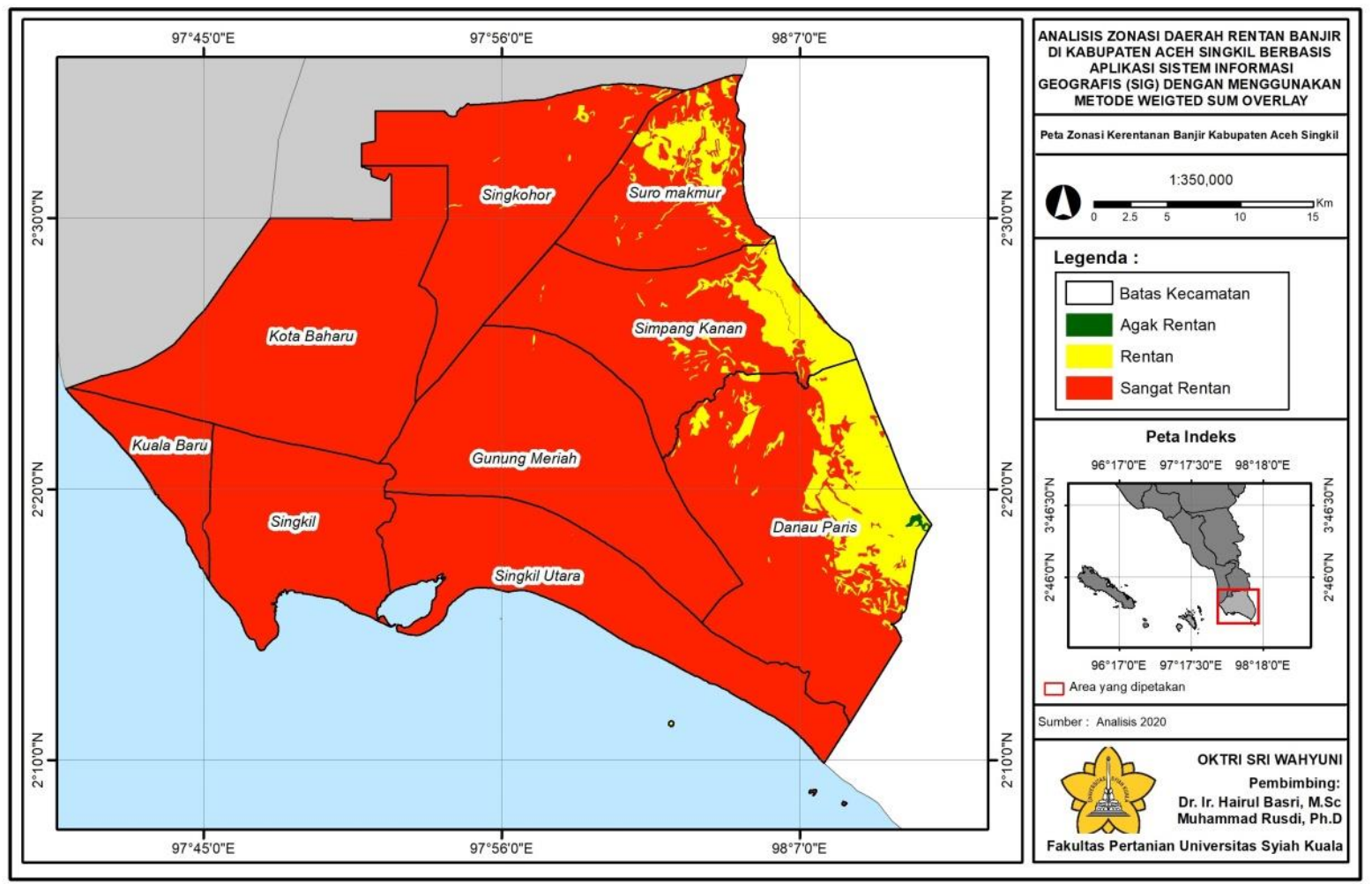

Gambar 7. Distribusi Kerentanan Banjir

\section{Perbandingan Kerentanan Banjir Weighted Sum Overlay dengan PDGA}

Pemetaan daerah rentan banjir pada Kabupaten Aceh Singkil sebelumnya telah dilakukan oleh Pusat Data Geospasial Aceh (PDGA) Bappeda Aceh (2017). Hasil antara analisis Weighted Sum Overlay dengan PDGA terdapat perbedaan jumlah kelas dan luasan pada masing-masing kelas kerentanan banjir. Untuk lebih rinci dapat dilihat pada tabel 7.

Tabel 7. Perbedaan Luas Kelas Kerentanan Banjir Weighted Sum Overlay dengan PDGA

\begin{tabular}{ccrrrrr}
\hline No & $\begin{array}{c}\text { Kelas Kerentanan } \\
\text { Banjir }\end{array}$ & $\begin{array}{c}\text { Weighted Sum } \\
\text { Overlay }\end{array}$ & $\%$ & PDGA (Ha) & $\%$ & $\begin{array}{c}\text { Perbedaan Luas } \\
\text { (Ha) }\end{array}$ \\
\hline 1 & Tidak Rentan & 0 & 0 & $1.458,94$ & 0,79 & $1.458,94$ \\
2 & Agak Rentan & 80,31 & 0,04 & $69.744,77$ & 37,54 & $69.664,46$ \\
3 & Rentan & $17.132,30$ & 9,22 & $107.859,27$ & 58,05 & $90.726,97$ \\
4 & Sangat Rentan & 168.590 & 90,74 & $6.739,64$ & 3,63 & $161.850,36$ \\
\hline & Total & $185.802,62$ & & $185.802,62$ & & \\
\hline
\end{tabular}

Berdasarkan Tabel 7 diatas menunjukkan adanya perbedaan yang signifikan antara hasil analisis Weighted Sum Overlay dengan PDGA. Kelas kerentanan banjir yang mendominasi 
pada PDGA berada pada kelas rentan dengan selisih 48,83\% dari Weighted Sum Overlay. Selisih antara kedua metode tersebut dikarenakan peta yang dihasilkan oleh PDGA di analisis dengan cakupan se-Aceh sehingga tingkat ketelitian tidak terlalu diperhitungkan. Sedangkan pada Weighted Sum Overlay kawasan kajian yang dilibatkan jauh lebih kecil sehingga hasilnya diperkirakan dapat lebih akurat. Secara spasial peta perbandingan hasil Weighted Sum Overlay dengan PDGA disajikan pada Gambar 8.

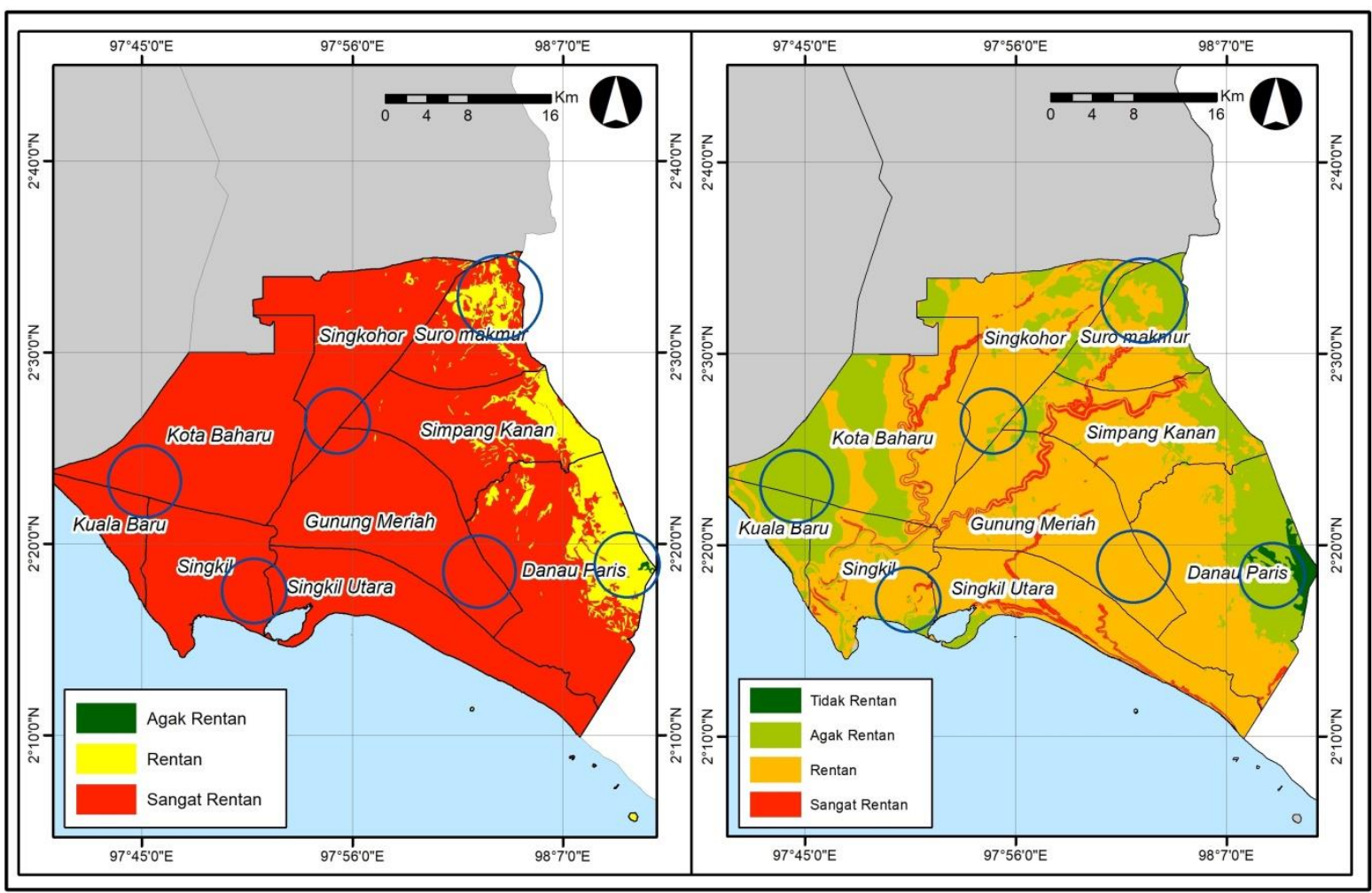

(a) Peta Kerentanan Hasil Analisis Weighted Sum Overlay

(b) Peta Kerentanan Hasil Analisis PDGA

Gambar 8. Peta Perbandingan Hasil Weighted Sum Overlay dengan PDGA

\section{Histori Kejadian banjir}

Berdasarkan data dari Badan Penanggulangan Bencana Daerah (BPBD) diketahui bahwa Kabupaten Aceh Singkil merupakan wilayah yang sering menjadi daerah langganan banjir dan sering terjadi banjir yaitu pada bulan Oktober - April. Hal ini mengindikasikan bahwa karakteristik banjir dilokasi penelitian bervariasi yang dipengaruhi oleh beberapa faktor seperti kondisi topografi, kondisi drainase, kepadatan bangunan, kondisi sungai saat curah hujan tinggi maupun saat bersamaan air pasang laut dan lain-lain. Peta histori kejadian banjir disajikan pada Gambar 9. 


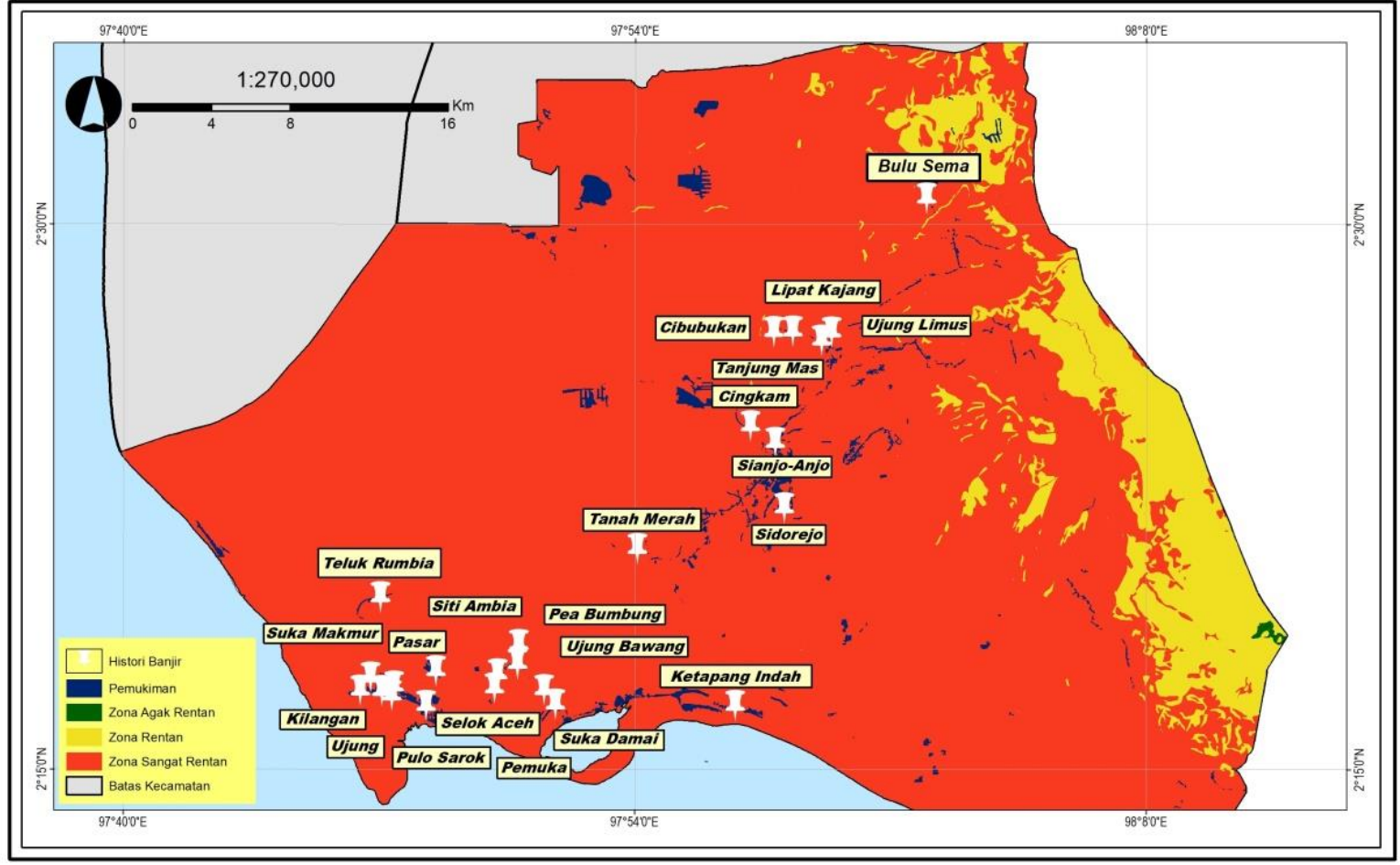

Gambar 9. Peta Histori Kejadian Banjir di Kabupaten Aceh Singkil

\section{SIMPULAN DAN SARAN}

\section{Simpulan}

Zonasi tingkat kerentanan banjir di Kabupaten Aceh Singkil terbagi dalam 3 zona yaitu zona agak rentan, zona rentan, dan zona sangat rentan. Pemetaan zonasi daerah rentan banjir di Kabupaten Aceh Singkil didominasi oleh kelas sangat rentan dengan persentase 90,74\% dari luas total lokasi penelitian, diikuti dengan kelas rentan 9,22\%, dan agak rentan 0,04\%. Faktor yang sangat mempengaruhi kerentanan banjir di Kabupaten Aceh Singkil adalah tingginya curah hujan dan kondisi topografi yang rendah serta adanya perubahan penggunaan lahan.

\section{Saran}

Diharapkan dapat dilakukan penelitian lebih lanjut dengan menggunakan wilayah cakupan yang lebih kecil dan parameter yang lebih kompleks serta diverifikasi dengan kejadian-kejadian banjir yang pernah terjadi untuk mendapatkan hasil yang lebih optimal. 


\section{DAFTAR PUSTAKA}

Badan Penanggulangan Bencana Daerah. 2019. Data-data Kejadian Bencana Alam Kabupaten Aceh. Aceh Singkil.

Maryono, A. 2005. Menangani Banjir, Kekeringan dan Lingkungan. Gadjah Mada University Press, Yogyakarta.

Pusat Data Geospasial Aceh. 2017. Peta Tingkat Kerawanan Banjir Provinsi Aceh. Bappeda Aceh. Aceh.

Puslittanak. 2004. Laporan Akhir Pengkajian Potensi Bencana Kekeringan, Banjir dan Longsor di Kawasan Satuan Wilayah Sungai Citarum-Ciliwung, Jawa Barat Bagian Barat Berbasis Sistem Informasi Geografi. Bogor.

Syukran, M. A. 2016. Pemanfaatan sistem informasi geografis untuk analisis tingkat kerawanan banjir (studi kasus daerah aliran sungai (DAS) Krueng Aceh). Tesis. Fakultas MIPA Universitas Syiah Kuala. Banda Aceh.

Undang-Undang Republik Indonesia Nomor 24 Tahun 2007 Tentang Penanggulangan Bencana.

Utomo W. Y. 2004. pemetaan kawasan berpotensi banjir di DAS Kaligarang Semarang dengan menggunakan sistem informasi geografis. Skripsi. Fakultas Pertanian Institut Pertanian Bogor, Bogor. 